\title{
Antifungal Effect of Zataria multiflora Essence on Experimentally Contami- nated Acryl Resin Plates With Candida albicans
}

\author{
Abbas Ali Jafari ${ }^{1}$; Abbas Falah Tafti ${ }^{2, *} ;$ Seyed Mehdi Hoseiny ${ }^{2}$; Abdolhossein Kazemi $^{3}$ \\ ${ }^{1}$ Department of Basic Science, Shahid Sadoughi University of Medical Sciences, Yazd, IR Iran \\ ${ }^{2}$ Department of Prostodontics, Shahid Sadoughi University of Medical Sciences, Yazd, IR Iran \\ 3 Infectious and Tropical Research Center, Tabriz University of Medical Sciences, Tabriz, IR Iran \\ ${ }^{*}$ Corresponding Author: Abbas Falah Tafti, Department of Prostodontics, Shahid Sadoughi University of Medical Sciences, Yazd, IR Iran. Tel: +98-9133519212, Fax: +98-3518367636, \\ E-mail: jaabno@gmail.com
}

Received: December 2, 2013; Revised: August 18, 2014; Accepted: September 15, 2014

\begin{abstract}
Background: Adherence and colonization of Candida species particularly C. albicans on denture surfaces, forms a microbial biofilm, which may result denture stomatitis in complete denture users.

Objectives: The purpose of the present study was to evaluate the antifungal effect Zataria multiflora essence in removing of Candida albicans biofilms on experimentally contaminated resin acryl plates.

Materials and Methods: In the present experimental study, 160 resin acrylic plates $(10 \times 10 \times 1 \mathrm{~mm})$ were contaminated by immersion in $1 \times 10^{3}$ C. albicans suspension for 24 hours to prepare experimental Candida biofilms. The total number of Candida cells, which adhered to 20 randomly selected acryl resin plates was determined as the Candia load before cleaning. The remaining 140 plates were divided to seven groups of 20 and immersed in five concentrations of Zataria multiflora essence from 50 to $3.125 \mathrm{mg} / \mathrm{mL}$ as test, 100000 IU nystatin as the positive and sterile physiologic serum as the negative control. The remaining Candida cells on each acryl plate were also enumerated and data were analyzed using the SPSS 16 software with Kruskal-Wallis and Wilcoxon tests.

Results: Zataria essence at concentrations of 50 and $25 \mathrm{mg} / \mathrm{mL}$ removed $100 \%$ of attached Candida cells similar to nystatine (MFC), while weaker Zataria essence solutions cleaned $88 \%, 60.5 \%$ and $44.7 \%$ of attached Candida cells. Kruskal-wallis test showed a statistically significant difference between all test groups $(\mathrm{P}=0.0001)$. In this study $12.5 \mathrm{mg} / \mathrm{mL}$ concentration of Zataria multiflora was considered as the minimum inhibitory concentration $\left(\mathrm{MIC}_{90}\right)$.

Conclusions: Zataria essence, at concentrations of 50 and $25 \mathrm{mg} / \mathrm{mL}$, effectively removed Candida cells that had adhered to the denture surface, similar to the level of removal observed for 100000 IU nystatin.
\end{abstract}

Keywords:Disinfection; Candida albicans; Acrylic Resins; multiflorol

\section{Background}

Dentures as an indwelling medical device in an individual's mouth, prepare an optimal environment for adhesion and colonization of both pathogenic and nonpathogenic organisms, and can cause inflammatory lesion of the oral mucosa (1). Denture stomatitis known as a chronic inflammatory condition of the palatal and alveolar mucosa underlying removable dental prostheses is seen in $15 \%$ to $65 \%$ of individuals (2) and is even more significant in the institutionalized denture wearing population with a rate of up to $72 \%(3,4)$. However denture stomatitis is usually asymptomatic and can be associated with burning, bleeding and unpleasant taste in denture users (5). Candida species, particularly C. albicans, which are a part of the human oral microbiota, have been reported as the main etiological agents responsible for the development of this inflammatory infection (6). Adherence of C. albicansto the host mucosal tissues (7) and also on the acrylic denture surfaces prepares reservoirs that produce proteolytic enzymes and damage mucosal tissues resulting in denture stomatitis (8).
In addition to Candida, most cariogenic bacteria especially Streptococcus mutants are also known as major etiological agents of dental caries, which adhere and accumulate on teeth surfaces, lead to plaque formation (9). It is believed that the attachment between microorganisms and the denture surface is due to electrostatic and hydrophobic interactions. These interactions may be disrupted by mechanical and chemical removal of microbial biofilms. Poor oral hygiene in patients with denture especially in case of badly fitted dentures promotes denture stomatitis. Regular cleaning and removal of microbial biofilm from denture surfaces is necessary for prevention and control of denture stomatitis in edentulous patients (10). There are numerous investigations in the dentistry literature advising the use of chemical solutions for denture disinfection (11-13); unfortunately these products cause mucosal allergic reactions, damage the acrylic resin and metal alloys of the dentures $(14,15)$.

The use of natural antimicrobials such as herbal mouthwashes has been recently increased as investigations

Copyright ( 2015, Iranian Red Crescent Medical Journal. This is an open-access article distributed under the terms of the Creative Commons Attribution-NonCommercial 4.0 International License (http://creativecommons.org/licenses/by-nc/4.0/) which permits copy and redistribute the material just in noncommercial usages, provided the original work is properly cited. 
Jafari A et al.

have indicated their potential to prevent oral diseases such as plaque-related diseases, particularly dental caries (16-18). Natural substances have been shown to possess antibacterial action mainly because most plants used in alternative medicine are composed of carvacrol and thymol, which act on bacterial cells disrupting their cytoplasmatic membrane and inhibiting their enzymatic activity $(19,20)$.

The specie Zataria multiflora (ZM) with the Persian name of Avishane Shirazi, has been used in traditional medicine for treatment of respiratory tract infections and managing irritable bowel syndrome (21), and as an antispasmodic, anesthetic, antinociceptive agent $(22,23)$. More recently its antibacterial and antifungal activities have also been demonstrated $(19,24,25)$. The antifungal activity of Zataria multiflora essence against several dermatophytes such as Trichophyton rubrum, Trichophyton mentagrophytes, Epidermophyton floccosum and saprophytes like Aspergillus flavus was reported by Effatpanah et al. (26). The purpose of the present study was to evaluate the antimicrobial effect of Zataria multiflora essence on experimentally produced C. albicans biofilms on resin acryl plates.

\section{Objectives}

This study was conducted to evaluate the antifungal effect Zataria multiflora essence in removing Candida albicans biofilm from experimentally contaminated resin acryl plates.

\section{Materials and Methods}

\subsection{Sample Size}

In order to reach a minimum of six unit difference in the average Candida colony counts between tested groups, a significance level of $5 \%, \alpha=5 \%, \beta=2 \%, S=80 \%$ and based on the following formula, 20 samples were chosen for each test and control groups.

$$
n=\frac{\left(Z_{\beta}+Z_{\frac{\alpha}{2}}\right)^{2} 2 s^{2}}{\left(x_{1}-x_{2}\right)^{2}}
$$

\subsection{Preparation of Acrylic Resin Plates}

In the present experimental study, 160 square shaped (10 $\times 10 \times 1 \mathrm{~mm}$ ) resin acrylic plates (Acropars, Marlic, Iran) were prepared (20 samples for each group) using thermally activated resin acrylic according to the manufacturer's instructions (Figure 1). The specimens were kept in a flask containing physiological serum ( $\mathrm{NaCl} 0.85 \%)$, sterilized in an autoclave (Labtron, Iran) at $121^{\circ} \mathrm{C}$ for 15 minutes (was calibrated based on manufactured instruction) and incubated at $4^{\circ} \mathrm{C}$ for further adherence testing.

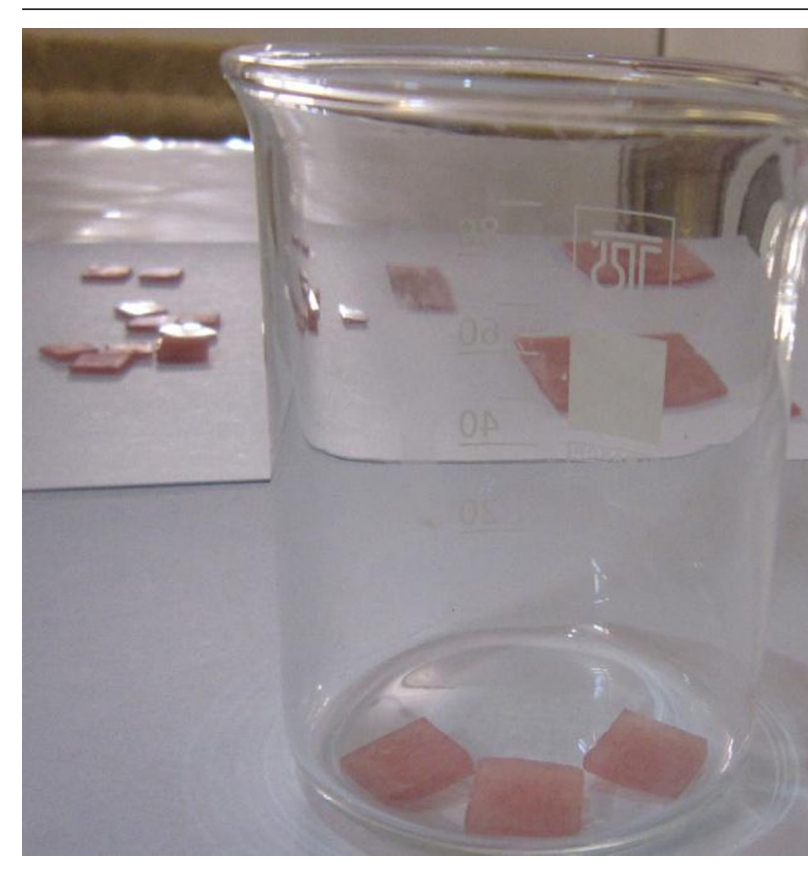

Figure 1. Acrylic Resin Plates Used for Experimental Contamination With C. albicans $(10 \times 10 \times 1 \mathrm{~mm})$

\subsection{Preparation of Fungal Suspension and Experi- mental Biofilm Formation}

Clinical isolates of C. albicans (ATCC 10231), cultured on Sabouraud dextrose agar plates (Merck, Germany) and incubated at $37^{\circ} \mathrm{C}$ for 24 hours, were used as test organisms for the current experimental study. An isolated fresh single colony was used for preparing Candida suspensions containing $1 \times 10^{3}$ viable cells per milliliter in sterile saline solution ( $\mathrm{NaCl} 0.85 \%$ ) using a hemocytometer. The experimental biofilm was created by immersing all acrylic resin plates in C. albicans suspension and incubating on a reciprocal shaker (100 RPM) at $37^{\circ} \mathrm{C}$ for 24 hours. Twenty resin plates were randomly selected, washed three times with sterile PBS, and transferred separately to a $50 \mathrm{~mL}$ sterile Falcon tube containing $5 \mathrm{~mL}$ of sterile PBS and glass pearls; the tubes were then agitated in a sonicator (Elma, Germany) for five minutes ( $45 \mathrm{KH} / 5$ minutes) to remove viable attached cells. Next, $10 \mu \mathrm{L}$ of each suspension was added to $90 \mu \mathrm{L}$ of sterile physiological solution and inoculated on Sabouraud dextrose agar (Merck, Germany) plates to evaluate attached viable cells before initiation of the disinfection protocol as a variable in the present study.

\subsection{Disinfection of Contaminated Acrylic Resin Plates}

The remaining 140 contaminated resin plates were randomly divided to seven groups of 20. Each group of plates were separately immersed in Zataria essence dilutions of 50 to $3.125 \mathrm{mg} / \mathrm{mL}$ (Baridge-essence, Kashan, Iran) 
Jafari A et al.

Table 1. Effectiveness of Zataria multiflora Essence and Percentage Removal of C. albicans From Twenty Experimentally Contaminated Resin Acryl Plates a

\begin{tabular}{|c|c|c|c|c|}
\hline Disinfectants & Initial Culture ${ }^{b}$ & After Disinfection ${ }^{b}$ & Removing Ability \% & PValue \\
\hline Nystatin (gold) & $721.5 \pm 67.3$ & 0 & 100 & 0.00001 \\
\hline DW (neg. control) & $721.5 \pm 67.3$ & $567 \pm 54$ & 20.1 & 0.062 \\
\hline $50 \mathrm{mg} / \mathrm{mL}$ Zataria & $721.5 \pm 67.3$ & 0 & 100 & 0.00001 \\
\hline $25 \mathrm{mg} / \mathrm{mL}$ Zataria & $721.5 \pm 67.3$ & 0 & 100 & 0.00001 \\
\hline $12.5 \mathrm{mg} / \mathrm{mL}$ Zataria & $721.5 \pm 67.3$ & $81.5 \pm 20.8$ & 90 & 0.0001 \\
\hline $6.25 \mathrm{mg} / \mathrm{mL}$ Zataria & $721.5 \pm 67.3$ & $285 \pm 38$ & 60.5 & 0.001 \\
\hline $3.125 \mathrm{mg} / \mathrm{mL}$ Zataria & $721.5 \pm 67.3$ & $399.5 \pm 45$ & 44.7 & 0.015 \\
\hline
\end{tabular}

a Abbreviation: DW, distilled water.

${ }^{b}$ Data are presented as mean $\pm S D$.

Table 2. Susceptibility Profile of Candida albicans to Zataria multiflora Essence Solution ${ }^{\text {a }}$

\begin{tabular}{|c|c|}
\hline Variable & Value, $\mathrm{mg} / \mathrm{mL}$ \\
\hline MFC & $<25$ \\
\hline MIC 90 & 12.5 \\
\hline MIC 50 & $>6.25$ \\
\hline
\end{tabular}

and 100000 IU nystatin solutions (gold standard) as test groups, as well as sterile physiologic solution ( $\mathrm{NaCl}$ 0.85\%) as the negative control group, in sterile Falcon tubes. All Falcon tubes were incubated on a reciprocal shaker (100 $\mathrm{RPM}$ ) at $37^{\circ} \mathrm{C}$ for two hours, washed three times as explained previously. Each single resin plate from all groups were then transferred to another sterile Falcon tube containing $5 \mathrm{~mL}$ of sterile PBS and glass pearls, agitated in a sonicator (Elma, Germany) for five minutes ( $45 \mathrm{KH} / 5 \mathrm{~min}$ utes calibrated based on the manufactured instructions) to remove the adhered viable Candida cells. Finally, $10 \mu \mathrm{L}$ of each washed solution was mixed with $90 \mu \mathrm{L}$ of sterile physiological solution and inoculated on Sabouraud dextrose agar plates in order to enumerate the attached viable Candida cells after the disinfection procedures.

\subsection{Statistical Tests}

The mean isolated Candida colonies ( $\mathrm{CFU} / \mathrm{mL}$ ) showed mean attached viable Candida cells in the seven groups, which were compared using the Kruskal-Wallis test. Wilcoxon statistical test was also used to compare the average counts of isolated Candida colonies before and after disinfection. Differences in the Candida removing ability of the tested solutions were considered significant if $\mathrm{P}$ $<0.05$. All statistical calculations were performed using the SPSS 15 software.

\section{Results}

The average number of viable C. albicans cells ( $\mathrm{CFU} / \mathrm{mL}$ $\pm \mathrm{SD}$ ), which adhered to the acrylic resin plates before and after disinfection, as well as the removing percent- age are illustrated in Table 1. Zataria essence solutions at concentrations of 50 and $25 \mathrm{mg} / \mathrm{mL}$ as well as $100000 \mathrm{IU}$ nystatin completely removed all adhered Candida cells from resin acryl plates as there were no isolated C. albicans colonies in the culture of their washing solutions. Concentration of $25 \mathrm{mg} / \mathrm{mL}$ of Zataria essence was determined as the minimum fungicidal concentration (MFC) in the present study. Concentration of $12.5 \mathrm{mg} / \mathrm{mL}$ of $\mathrm{Za}$ taria essence removed about $90 \%$ of attached Candida viable cells and this concentration was considered as the minimum inhibitory concentration $\left(\mathrm{MIC}_{90}\right)$ in the present study (Table 2). There was no statistically significant difference between the average Candida colonies isolated from cultures of resin acryl plates incubated with 50 and $25 \mathrm{mg} / \mathrm{mL}$ Zataria, and 100000 nystatin solutions (P $=0.00001$ ).

\section{Discussion}

There are different chemical mouth washes, which are commonly used for controlling various plaque formations on teeth and dentures; they may cause an allergic response and probable mucosal alterations (27). There are many reports that discourage patients to use these mouthwashes as a result of their several side effects such as undesirable tooth and denture discoloration, unpleasant taste, dryness and burning sensation in the mouth $(14,28)$. However in the general worldwide population, herbal medicines are popular, many modern medicines are still derived from herbs (29). Zataria multiflora, which grows naturally in central and southern parts of Iran, is used in traditional herbal medicines for its antiseptic, analgesic and carminative properties $(22,30)$.

The antimicrobial activity of Z. multiflora essence against C. albicans on experimentally contaminated acryl resin plates was evaluated in the present study. A standard broth macrodilution method introduced by the clinical and laboratory standard institute (CLSI) was employed in the current study (31). As indicated in Table 1, concentrations of 50 and $25 \mathrm{mg} / \mathrm{mL}$ of Zataria essence completely cleaned contaminated acryl resin plates (100\%) since there were no viable Candida cells, in the culture of their 
washing solution. Concentration of $25 \mathrm{mg} / \mathrm{mL}$ of Zataria essence was also determined as the minimum fungicidal concentration (MFC) in the present study. Results of the current study was supported by the study of Zia et al.which showed the anti-Candida properties of Zataria extract against $C$. albicans isolated from patients with oral candidiasis (32). Akbari also reported antifungal ranges of 0.5 to $125 \mathrm{mg} / \mathrm{mL}$ for aqueous extracts of Zataria against different Candida species (33).

This wide range of effective Zataria concentrations in Akbari's study unlike the outcome of present study may results from difference in methods, as they used disk diffusion, whereas the broth dilution method was used in the current study.

Mahmoudabadi et al. in an in vitro study for anti-Candida activity of methanolic Z. multiflora Boiss reported the concentration of $70.7 \mathrm{mg} / \mathrm{mL}$ as the MIC, which is more than the MIC of the present study (24).

Different chemical compounds including thymol, carvacrol, p-cymene and linalool were isolated from the aerial parts of this plant $(28,34)$ and the anti-Candida activity of aqueous essence of $Z$. multiflora on contaminated resin acryl is probably due to the above-mentioned essential oils. Anti-erythema effect of Z. multiflora essence in comparison with miconazole gel in denture stomatitis was reported by Amanlou et al. (28), which supported the results of the current study. However in their study Z. multiflora extracts did not reduce the colony count of Candida albicans on denture surface as efficiently as miconazole; concentrations of 50 and $12.5 \mathrm{mg} / \mathrm{mL}$ of Zataria essence in the current study showed reduction in the colony counts of $C$. albicans on resin acryl plates as efficiently as nystatin.

Besides antifungal effects, asignificant antibacterial efficiency for Z. multiflora essential oils against clinical isolates of $S$. aureus, especially MRSA was also reported (25). Antiviral activity of $Z$. multiflora extracts was also reported against Herpes simplex type 1 virus at concentrations of 800 and $1000 \mu \mathrm{g} / \mathrm{mL}$ by Arabzadeh et al. (35). Since $Z$. multiflora increased IFN- $\gamma$, decreased IL-4, and enhanced the ratio of IFN- $\gamma$ to IL-4 (Th1/Th2 balance), it may have a therapeutic value in inflammatory responses such as allergies, autoimmunity and infectious diseases associated with Th1/Th2 imbalance (36). The immunomodulatory activity of the Z. multiflora on dendritic cells and T cell responses was also shown, which resulted from decreasing proliferation of mitogen-stimulated lymphocytes (37).

In the present in vitro study, concentrations of 50 and $25 \mathrm{mg} / \mathrm{mL}$ of Zataria essence effectively removed Candida cells from experimentally contaminated resin acryl plates as efficiently as $100000 \mathrm{IU}$ nystatin.

\section{Acknowledgements}

The authors would like to thank the Dentistry School for their support and MS Ghafoorzadah for her kind laboratory cooperation.

\section{Authors' Contributions}

Abbas Falah Tafti and Abbas Ali Jafari supervised the study, participated in designing and conducting the study and prepared the manuscript. Seyed Mehdi Hosseiny carried out the study and collected the data. Abdolhossein Kazemei performed the statistical analysis. All authors have studied and approved the content of the present manuscript.

\section{Funding/Support}

This study was a Dentistry thesis (no. 522) supported by Shahid Sadoughi University of Medical Sciences, Yazd, Iran.

\section{References}

1. Lalla RV, Patton LL, Dongari-Bagtzoglou A. Oral candidiasis: pathogenesis, clinical presentation, diagnosis and treatment strategies. J CalifDent Assoc. 2013;41(4):263-8.

2. Radford DR, Challacombe SJ, Walter JD. Denture plaque and adherence of Candida albicans to denture-base materials in vivo and in vitro. Crit Rev Oral Biol Med.1999;10(1):99-116.

3. Daniluk T, Tokajuk G, Stokowska W, Fiedoruk K, Sciepuk M, Zaremba ML, et al. Occurrence rate of oral Candida albicans in denture wearer patients. Adv Med Sci. 2006;51 Suppl 1:77-80.

4. Perea C, Suarez-Garcia MJ, Del Rio J, Torres-Lagares D, Montero J Castillo-Oyague R. Oral health-related quality of life in complete denture wearers depending on their socio-demographic background, prosthetic-related factors and clinical condition. $\mathrm{Med}$ Oral Patol Oral Cir Bucal. 2013;18(3):e371-80.

5. Webb BC, Thomas CJ, Willcox MD, Harty DW, Knox KW. Candidaassociated denture stomatitis. Aetiology and management: a review. Part 2. Oral diseases caused by Candida species. Aust Dent J. 1998;43(3):160-6.

6. Calcaterra R, Pasquantonio G, Vitali LA, Nicoletti M, Di Girolamo $\mathrm{M}$, Mirisola C, et al. Occurrence of Candida species colonization in a population of denture-wearing immigrants. Int J Immunopathol Pharmacol. 2013;26(1):239-46.

7. Mayahara M, Kataoka R, Arimoto T, Tamaki Y, Yamaguchi N, WatanabeY, et al. Effects of surface roughness and dimorphism on the adhesion of Candida albicans to the surface of resins: scanning electron microscope analyses of mode and number of adhesions. J Investig Clin Dent. 2014;5(4):307-12.

8. Skupien JA, Valentini F, Boscato N, Pereira-Cenci T. Prevention and treatment of Candida colonization on denture liners: a systematic review. J Prosthet Dent. 2013;110(5):356-62.

9. Kang MS, Kang IC, Kim SM, Lee HC, Oh JS. Effect of Leuconostoc spp. on the formation of Streptococcus mutans biofilm. J Microbiol. 2007;45(4):291-6.

10. Budtz-Jorgensen E, Mojon P, Rentsch A, Deslauriers N. Effects of an oral health program on the occurrence of oral candidosis in a long-term care facility. Community Dent Oral Epidemiol. 2000;28(2):141-9.

11. Consani RL, Azevedo DD, Mesquita MF, Mendes WB, Saquy PC. Ef fect of repeated disinfections by microwave energy on the physical and mechanical properties of denture base acrylic resins. Braz Dent J. 2009;20(2):132-7.

12. Paranhos Hde F, Davi LR, Peracini A, Soares RB, Lovato CH, Souza RF. Comparison of physical and mechanical properties of microwave-polymerized acrylic resin after disinfection in sodium hypochlorite solutions. Braz Dent J. 2009;20(4):331-5.

13. Pinto Lde R, Acosta EJ, Tavora FF, da Silva PM, Porto VC. Effect of repeated cycles of chemical disinfection on the roughness and hardness of hard reline acrylic resins. Gerodontology. 2010;27(2):147-53.

14. Zanatta FB, Antoniazzi RP, Rosing CK. Staining and calculus formation after $0.12 \%$ chlorhexidine rinses in plaque-free and plaque covered surfaces: a randomized trial. J Appl Oral Sci. 2010;18(5):515-21 
15. Pemberton MN, Gibson J. Chlorhexidine and hypersensitivity reactions in dentistry. Br Dent J. 2012;213(11):547-50.

16. Yamaguti-Sasaki E, Ito LA, Canteli VC, Ushirobira TM, Ueda-Nakamura T, Dias Filho BP, et al. Antioxidant capacity and in vitro prevention of dental plaque formation by extracts and condensed tannins of Paullinia cupana. Molecules. 2007;12(8):1950-63.

17. Smullen J, Koutsou GA, Foster HA, Zumbe A, Storey DM. The antibacterial activity of plant extracts containing polyphenols against Streptococcus mutans. Caries Res. 2007;41(5):342-9.

18. Muanza DN, Kim BW, Euler KL, Williams L. Antibacterial and Antifungal Activities of Nine Medicinal Plants from Zaire. Int J Pharmacogn. 1994;32(4):337-45.

19. Saei-Dehkordi SS, Tajik H, Moradi M, Khalighi-Sigaroodi F. Chemical composition of essential oils in Zataria multiflora Boiss. from different parts of Iran and their radical scavenging and antimicrobial activity. Food Chem Toxicol. 2010;48(6):1562-7.

20. Yaltirak T, Aslim B, Ozturk S, Alli H. Antimicrobial and antioxidant activities of Russula delica Fr. Food Chem Toxicol. 2009;47(8):2052-6.

21. Aynehchi Y. Pharmacognosy and Medicinal Plants of Iran.Tehran: Tehran University Press; 1991.

22. Zargari A. Medicinal Plants.Tehran: Tehran University Press;1990.

23. Ramezani M, Hosseinzadeh H, Samizadeh S. Antinociceptive effects of Zataria multiflora Boiss fractions in mice. J Ethnopharmacol. 2004;91(1):167-70.

24. Mahmoudabadi AZ, Dabbagh MA, Fouladi Z. In vitro anti-Candida Activity of Zataria multiflora Boiss. Evid Based Complement Alternat Med. 2007;4(3):351-3.

25. Mahboubi M, Feizabadi MM, Safara M. Antifungal activity of essential oils from Zataria multiflora, Rosmarinus officinalis, Lavandula stoechas, Artemisia sieberi Besser and Pelargonium graveolens against clinical isolates of Candida albicans. Pharmacognosy Magazine. 2008;4:S15-8.

26. Effatpanah H, Sabokbar A, Kordbacheh P, Bahonar AR, Bayat M, Saeednejad L. Antifungal effect of Zataria multiflora: An in vitro evaluation. Global Veterinaria. 2010;4(2):140-3.
27. Chitsazi M, Shirmohammadi A, Balayi E. [Effect of herbal and chemical mouth-rinses on periodontal indices; comparison of matrica, persica and chlorhexidine]. 2007;8(4):54-60.

28. Amanlou M, Beitollahi JM, Abdollahzadeh S, Tohidast-Ekrad Z. Miconazole gel compared with Zataria multiflora Boiss. gel in the treatment of denture stomatitis. Phytother Res. 2006;20(11):966-9.

29. Cooper EL. CAM, eCAM, Bioprospecting: The 21st Century Pyramid. Evid Based Complement Alternat Med. 2005;2(2):125-7.

30. Hosseinzadeh H, Ramezani M, Salmani G. Antinociceptive, anti-inflammatory and acute toxicity effects of Zataria multiflora Boiss extracts in mice and rats. J Ethnopharmacol. 2000;73(3):379-85.

31. Espinel-Ingroff A, Fothergill A, Ghannoum M, Manavathu E, Ostrosky-Zeichner L, Pfaller M, et al. Quality control and reference guidelines for CLSI broth microdilution susceptibility method (M 38-A document) for amphotericin B, itraconazole, posaconazole, and voriconazole. J Clin Microbiol. 2005;43(10):5243-6.

32. Zia MA, Bayat $M$, Khalkhali $H$. In vitro antifungal effect of Thymus vulgaris essence on Candida albicans isolated from patients with oral candidiasis. J Shahrekord Univ Med Sci. 2011;13(3):44-52.

33. Akbari S. Antifungal activity of Thymus vulgaris L. and Origanum vulgare L. against fluconazol-resistant and susceptible Candida albicans isolates. J Med Plants. 2007;6(1):53-62.

34. Saleem M, Nazli R, Afza N, Sami A, Ali MS. Biological significance of essential oil of Zataria multiflora boiss. Nat Prod Res. 2004;18(6):493-7.

35. Arabzadeh AM, Ansari-Dogaheh M, Sharififar F, Shakibaie M, Heidarbeigi M. Anti herpes simplex-1 activity of a standard extract of Zataria multiflora Boiss. PakJ Biol Sci. 2013;16(4):180-4.

36. Boskabady MH, Mehrjardi SS, Rezaee A, Rafatpanah H, Jalali S. The impact of Zataria multiflora Boiss extract on in vitro and in vivo Th1/Th2 cytokine (IFN-gamma/IL4) balance. J Ethnopharmacol. 2013;150(3):1024-31.

37. Amirghofran Z, Ahmadi H, Karimi MH. Immunomodulatory activity of the water extract of Thymus vulgaris, Thymus daenensis, and Zataria multiflora on dendritic cells and T cells responses. J Immunoassay Immunochem. 2012;33(4):388-402. 